\title{
An Overview on Agroecology and Organic Agriculture Strategies for Sustainable Crop Production
}

\author{
Mariangela Diacono $^{1, *(\mathbb{D})}$, Alessandra Trinchera ${ }^{2} \mathbb{D}$ and Francesco Montemurro ${ }^{1}$ (D) \\ 1 Council for Agricultural Research and Economics, Research Centre for Agriculture and Environment, \\ Via Celso Ulpiani 5, 70125 Bari, Italy; francesco.montemurro@crea.gov.it \\ 2 Council for Agricultural Research and Economics, Research Centre for Agriculture and Environment, \\ Via della Navicella 2-4, 00184 Roma, Italy; alessandra.trinchera@crea.gov.it \\ * Correspondence: mariangela.diacono@crea.gov.it; Tel.: +39-080-5475052
}

check for

updates

Citation: Diacono, M.; Trinchera, A.; Montemurro, F. An Overview on Agroecology and Organic Agriculture Strategies for Sustainable Crop Production. Agronomy 2021, 11, 223. https://doi.org/10.3390/ agronomy11020223

Received: 4 January 2021

Accepted: 20 January 2021

Published: 25 January 2021

Publisher's Note: MDPI stays neutral with regard to jurisdictional claims in published maps and institutional affiliations.

Copyright: (c) 2021 by the authors. Licensee MDPI, Basel, Switzerland. This article is an open access article distributed under the terms and conditions of the Creative Commons Attribution (CC BY) license (https:/ / creativecommons.org/licenses/by/ $4.0 /)$.
Within the new "European Green Deal", the European Commission defined crucial challenges for the agriculture of future decades, such as making food production more sustainable by considering the local pedo-climatic and socio-economic specificities. To meet the European Green Deal objectives, contributing to the Farm to Fork, Biodiversity 2030 and Zero Pollution strategies, win-win solutions at the farm and territory levels are required, allowing a reduction in air, water and soil pollution and loss of biodiversity and natural resources, as well as waste production/disposal.

This Special Issue (SI) collects current research findings dealing with different agricultural practices, particularly addressing agroecology and organic farming, and their sustainability assessment. In particular, the SI contains seventeen selected papers, which concern a wide range of topics. The papers referred to two main subjects, though some of them report both: (i) adopting agroecological approaches and organic agriculture practices and (ii) assessing their impact, including trade-offs with regard to the three pillars of sustainability.

The COVID-19 pandemic highlighted the importance of resilient food systems focusing on a circular economy. In this perspective, Pergola et al. [1] proposed on-farm composting to recycle two types of agricultural waste from horticultural farms, evaluating the environmental impacts of the composting process, during a 20-year period. Results pointed out that the compost with dry matter above $10 \%$ was the most sustainable one. Navarro et al. [2] proposed an integrated management system using manure from livestock, duly composted, to fertilize celery: results showed a better crop yield and quality parameters than in mineral fertilization treatments, confirming the sustainability of the integrated cropping system.

The impact of organic amendments on crop yield and soil fertility has been under study worldwide for a long time, resulting as crucial for sustainable agroecosystem management. Focusing on rainfed rice performance in rural floodplain environments of East Africa, in Kwesiga et al. [3], the effects of repeated applications of green and farmyard manures were evaluated. The authors found that both amendments led to a significant increase in grain yield (by 18-62\%), reporting in the third year also a positive residual effect on the yield of non-amended rice, and increased soil fertility.

Cover crops use is increasing in different cropping systems, since it is one of the smartest agroecological practices accelerating the transition to sustainable farming. In fact, in Gattullo et al. [4], cover crop (i.e., fescue) introduction in vineyards determined an organic C increase by $136 \%$, without significantly influencing grape quality and yield. Similarly, Tarricone et al. [5] pointed out that legume cover crop use is a sustainable soil management tool, which improved soil organic matter in the studied organic vineyards. In a four-year organic vegetable rotation, cover crop introduction such as living mulch combined with no till proved to enhance the quality of biomass to be recycled, thus allowing 
for effectively closing the loop, showing high energy efficiency [6]. A communication by Mgolozeli et al. [7], which referred to a permanent soil cover mulching technology, named "agrimat", attested its positive effects on soil erosion prevention, improvement in soil quality and crop productivity. Moreover, Kraska et al. [8] found that lentil intercropping with oats, reducing crop lodging, increased competitiveness against weeds with a nonsignificant reduction in crop yield.

The benefit of cover crops for agroecosystems was also underlined by Moore et al. [9], who found that seeding pennycress after sweet corn crops did reduce residual mineral nitrogen in the soil compared to leaving the ground fallow, thus serving as an effective catch crop. Further, a study in northwestern China showed that maximizing the cereal/legume intercropping performance by increasing the density of maize alleviates the inhibitory effect of soil mineral $\mathrm{N}$ on the nodulation of intercropped pea [10]. In addition to positive effects of cover cropping on nutrient availability, the beneficial impact on predator insect dynamics should be considered. In Adhikari et al. [11], 5-year study results indicated that crop-livestock integration, organic farming and cover cropping enhance activity density, species richness, diversity and evenness of the ground beetle, thus allowing the biological control of pests.

Organic farmers depend on cultivars supplied by conventional plant breeders; therefore, a study in Poland compared 10 winter triticale varieties to identify the most appropriate cultivars for organic cultivation [12]. Results allowed identifying cultivars with high and low yielding potential, competitiveness against weeds and resistance to fungal pathogens.

In a sustainable agriculture context, among different practices for cropping systems management, no-tillage with $25-30 \mathrm{~cm}$ tall wheat straw proved to greatly decrease the rate of soil erosion at various wind velocities, by increasing non-erodible soil aggregates, particularly in a two-year wheat-winter rape-maize rotation [13]. Integration of organic management practices with conservation agriculture techniques can be considered a winwin strategy: in a two-year rotation experiment with seven cash crops, Ceccanti et al. [14] showed that cultivation with an integrated system (organic cover crop-based no-tillage system) allowed obtaining fruits and vegetables with higher levels of bioactive compounds, particularly improving the nutraceutical values of vegetables. Another relevant topic in the Farm to Fork and Zero Pollution strategies deals with the external inputs to be used in food production to guarantee food quality. The study of Trinchera et al. [15] focused on understanding the origin of phosphonic acid contamination in several organic horticultural crops, through a multi-actor participative approach. The authors demonstrated that crops were not able to self-synthetize phosphonic acid, while it was derived from the application of contaminated fertilizers/plant protection products or, in tree crops, from their ability to store phosphonic acid in their woody organs for several years.

As stated by Guarnaccia et al. [16], shifting to sustainable food systems is a multidimensional and complex process. In their case study, a bioregional strategic framework was proposed for a sustainable food system for Sicily, trying to mobilize stakeholders towards a coordinated approach. Results showed the opportunity of creating a new, equitable, more resilient food system. In West Africa, a network of stakeholders is developing initiatives for scaling up agroecological practices despite low institutional initiatives [17]. However, the best solution consists in farmers being supported in this process by public decision-makers as well as other stakeholders (e.g., researchers), in order to attain an efficient agroecological transition.

Funding: This research received no external funding.

Conflicts of Interest: The authors declare no conflict of interest. 


\section{References}

1. Pergola, M.; Persiani, A.; Pastore, V.; Palese, A.M.; D'Adamo, C.; De Falco, E.; Celano, G. Sustainability Assessment of the Green Compost Production Chain from Agricultural Waste: A Case Study in Southern Italy. Agronomy 2020, 10, 230. [CrossRef]

2. Navarro, A.S.; Romero, J.A.S.; Sanjuan, M.C.S.; Bernardeau, M.A.B.; Delgado Iniesta, M.J. Medium-Term Influence of Organic Fertilization on the Quality and Yield of a Celery Crop. Agronomy 2020, 10, 1418. [CrossRef]

3. Kwesiga, J.; Grotelüschen, K.; Senthilkumar, K.; Neuhoff, D.; Döring, T.F.; Becker, M. Effect of Organic Amendments on the Productivity of Rainfed Lowland Rice in the Kilombero Floodplain of Tanzania. Agronomy 2020, 10, 1280. [CrossRef]

4. Gattullo, C.E.; Mezzapesa, G.N.; Stellacci, A.M.; Ferrara, G.; Occhiogrosso, G.; Petrelli, G.; Castellini, M.; Spagnuolo, M. Cover Crop for a Sustainable Viticulture: Effects on Soil Properties and Table Grape Production. Agronomy 2020, 10, 1334. [CrossRef]

5. Tarricone, L.; Debiase, G.; Masi, G.; Gentilesco, G.; Montemurro, F. Cover Crops Affect Performance of Organic Scarlotta Seedless Table Grapes Under Plastic Film Covering in Southern Italy. Agronomy 2020, 10, 550. [CrossRef]

6. Montemurro, F.; Persiani, A.; Diacono, M. Cover Crop as Living Mulch: Effects on Energy Flows in Mediterranean Organic Cropping Systems. Agronomy 2020, 10, 667. [CrossRef]

7. Mgolozeli, S.; Nciizah, A.D.; Wakindiki, I.I.C.; Mudau, F.N. Innovative Pro-Smallholder Farmers' Permanent Mulch for Better Soil Quality and Food Security Under Conservation Agriculture. Agronomy 2020, 10, 605. [CrossRef]

8. Kraska, P.; Andruszczak, S.; Kwiecińska-Poppe, E.; Staniak, M.; Różyło, K.; Rusecki, H. Supporting Crop and Different Row Spacing as Factors Influencing Weed Infestation in Lentil Crop and Seed Yield under Organic Farming Conditions. Agronomy 2020, 10, 9. [CrossRef]

9. Moore, S.A.; Wells, M.S.; Gesch, R.W.; Becker, R.L.; Rosen, C.J.; Wilson, M.L. Pennycress as a Cash Cover-Crop: Improving the Sustainability of Sweet Corn Production Systems. Agronomy 2020, 10, 614. [CrossRef]

10. Zhao, C.; Fan, Z.; Coulter, J.A.; Yin, W.; Hu, F.; Yu, A.; Fan, H.; Chai, Q. High Maize Density Alleviates the Inhibitory Effect of Soil Nitrogen on Intercropped Pea. Agronomy 2020, 10, 248. [CrossRef]

11. Adhikari, S.; Menalled, F.D. Supporting Beneficial Insects for Agricultural Sustainability: The Role of Livestock-Integrated Organic and Cover Cropping to Enhance Ground Beetle (Carabidae) Communities. Agronomy 2020, 10, 1210. [CrossRef]

12. Feledyn-Szewczyk, B.; Nakielska, M.; Jończyk, K.; Berbeć, A.K.; Kopiński, J. Assessment of the Suitability of 10 Winter Triticale Cultivars (x Triticosecale Wittm. ex A. Camus) for Organic Agriculture: Polish Case Study. Agronomy 2020, 10, 1144. [CrossRef]

13. Yang, C.; Geng, Y.; Fu, X.Z.; Coulter, J.A.; Chai, Q. The Effects of Wind Erosion Depending on Cropping System and Tillage Method in a Semi-Arid Region. Agronomy 2020, 10, 732. [CrossRef]

14. Ceccanti, C.; Landi, M.; Antichi, D.; Guidi, L.; Manfrini, L.; Monti, M.; Tosti, G.; Frasconi, C. Bioactive Properties of Fruits and Leafy Vegetables Managed with Integrated, Organic, and Organic No-Tillage Practices in the Mediterranean Area: A Two-Year Rotation Experiment. Agronomy 2020, 10, 841. [CrossRef]

15. Trinchera, A.; Parisi, B.; Baratella, V.; Roccuzzo, G.; Soave, I.; Bazzocchi, C.; Fichera, D.; Finotti, M.; Riva, F.; Mocciaro, G.; et al. Assessing the Origin of Phosphonic Acid Residues in Organic Vegetable and Fruit Crops: The Biofosf Project Multi-Actor Approach. Agronomy 2020, 10, 421. [CrossRef]

16. Guarnaccia, P.; Zingale, S.; Scuderi, A.; Gori, E.; Santiglia, V.; Timpanaro, G. Proposal of a Bioregional Strategic Framework for a Sustainable Food System in Sicily. Agronomy 2020, 10, 1546. [CrossRef]

17. Tapsoba, P.K.; Aoudji, A.K.N.; Kabore, M.; Kestemont, M.-P.; Legay, C.; Achigan-Dako, E.G. Sociotechnical Context and Agroecological Transition for Smallholder Farms in Benin and Burkina Faso. Agronomy 2020, 10, 1447. [CrossRef] 